\title{
Participation in Decision Making, Productivity and Job Satisfaction among Managers of Fish Farms in Greece
}

\author{
Sophia Anastasiou ${ }^{1}$, Kostas Karipoglou ${ }^{2} \&$ Cosmas Nathanailides ${ }^{3}$ \\ ${ }^{1}$ Dept. Logistics, TEI of Central Greece, THiva, Greece \\ ${ }^{2}$ School of Agricultural Sciences, TEI of Epirus, Arta, Greece, \\ ${ }^{3}$ Dept. Aquaculture \& Fisheries, TEI of West Greece, Messolonghi, Greece \\ Correspondence: Sophia Anastasiou, Dept. Logistics, School of Management, TEI of Central Greece, Thiva, \\ Greece. Tel: 302-262-022-569. E-mail: anastasiou@yahoo.com
}

Received: September 24, 2014

Accepted: October 8, $2014 \quad$ Online Published: November 25, 2014

doi:10.5539/ibr.v7n12p92

URL: http://dx.doi.org/10.5539/ibr.v7n12p92

\begin{abstract}
A survey of production Managers in Greek fish farms was used to evaluate their level of job satisfaction and factors affecting it. Production Managers in Greek Fish farms exhibited high level of job satisfaction with more than $44 \%$ of them exhibiting job satisfaction levels $>70$. The majority (77.7\%) of the sample had age $>30$ and $44 \%$ of them had postgraduate qualifications. The length of service varied between 6 and 20 years with an average 13.72 years of service. The annual salary ranged between $22 \mathrm{~K}$ and $38 \mathrm{~K}$ with an average of 30,670 Euros. The perceived level of participation of the staff in the decision making process of the company was high with values ranging from 3 (a low degree of participation) to 7(high degree of participation). The results indicate that job satisfaction is mostly increased with increasing level of participation in the decision making, wages and age and less by the productivity of the fish farm. Interestingly, the data presented here, indicate a negative effect of the length of stay (Spearman's correlation $=-0.24, \mathrm{P}<0.05$ ) on job satisfaction. This is an alarming result, production managers may be experience difficulties in coping with the current difficult economic conditions that Greek fish farms are exposed to as a results of the financial crisis. Under these adverse economic conditions of Greece, several businesses including the fish farms reduced the volume of production, the number of their employees and the wages and bonuses.
\end{abstract}

Keywords: managers, job satisfaction, aquaculture, decision making

\section{Introduction}

Organizations which have goals to achieve, require happy, motivated and satisfied human resources (Bush \& Middlewood, 2006; Papakonstantinou \& Anastasiou, 2013) and is the task of the organizations to analyse the factors that influence their employees' motivation, job satisfaction and work performance.

Job satisfaction can be defined as an affective or emotional state response towards various aspects of an individual's work (Ellickson \& Logsdon, 2001). It may influence various work aspects within an organization such as efficiency, productivity, absenteeism, turnover rates and human resources' well-being (Maghradi, 1999; Amin et al., 2014).) Job satisfaction in the workplace may vary according to several parameters including the expectations of the workforce, personality and cultural differences (Kristensen \& Johansson, 2008).

The job satisfaction of employees in Agricultural business, including the fish farms, has not received much attention by researchers in Greece and historically, little attention has been given for Human resources management of agricultural business. This neglect creates a lack of research data and a knowledge gap for the levels of job satisfaction in Aquaculture personnel. Published papers for the job satisfaction of Greek employees are focused on few business sectors which did not include Agricultural workers, including Fish farm personnel (Markovits, 2007).

\section{Literature Review}

In the literature, there are a plethora of definitions regarding job satisfaction and work motivation. Several intrinsic and extrinsic variables can influence the levels of employee's job satisfaction. Job satisfaction can be defined as an affective or emotional state response towards various aspects of an individual's work (Spector, 
1997; Ellickson \& Logsdon, 2002). Robbins et al. (2003) define job satisfaction as "the difference between the rewards employees receive and the reward they believe they should receive". It may influence various aspects at work such as productivity, efficiency, absenteeism, turnover rates and workers' well-being in general (Maghradi, 1999).

Job satisfaction may vary according to human resource management practices including motivation, job recognition, rewards and career prospects and organizational commitment (Danish \& Usman, 2010; Mullins, 2002). The relationship between motivation and job satisfaction is not clear, it can be illustrated by means of the motivational theories which can be classified into two main categories; 'content' and 'process' theories (Brown $\&$ Peterson, 1994). 'Content theories' are specifically related to job satisfaction and assume a direct relationship between job satisfaction and improved performance, while the 'process theories' look in more detail the relationship between motivation, satisfaction and performance (Mullins, 2002). Nel et al. (2004) refers to content theories as the 'what' of motivation and to process theories as the 'how' of motivation.

Cultural differences of the personnel and the organizational culture can influence the managerial policies, values and job expectations of managers and employees with significant effect on the levels of job satisfaction (Hofstede, 1980; Sempane et al., 2002; Naqvi et al., 2013). Compared to collectivist nations, job satisfaction levels may be greater in individualistic than collectivist nations. According to a classification of countries Greece is viewed as noticeably different from the Anglo cluster of countries, Greece is a culture high in power distance and uncertainty avoidance as well as collectivist (Green et al., 2005; Simosi, 2013). The Greek management is characterized by the fear of responsibility and the low belief on others' knowledge and capacity (Bourantas et al. 1990). Nevertheless, Greek employees have been found to demonstrate strong identification with their work organizations (Markovits et al., 2007) indicating the commitment of the employees to their jobs.

The Managers may exhibit a level of job satisfaction which may vary according to personality and working conditions (Maghradi, 1999; Yurtseven \& Halici, 2012). Job satisfaction, productivity and work load of employees can change according to the financial conditions that a company is exposed to and according to the structure, size and maturity of the business and the sector in each country (Anastasiou \& Papakostantinou, 2014; Erbasi \& Arat, 2012; Gazioglu \& Aysit, 2006). For example, the Greek aquaculture industry is currently experiencing severe financial problems but also very high productivity. The total volume of production and the cost of production including the labour cost of the marine fish farms in Greece changed dramatically during the financial economic crisis (Anastasiou et al., 2014, Tyligadas et al., 2014).

During the early 1990s, several small fish farms were bought or merged with larger companies with benefits for the cost of production through scale economy, technological changes and labour productivity. The aquaculture industry in Greece, particularly the marine aquaculture sector is thriving in term of productivity and growth exhibiting rapid increase in the volume of production and in the technological innovation. Nevertheless, recently the aquaculture industry in Greece managed to survive during adverse economic conditions, a period of national and European and Global economic crisis (Tveteras \& Lien, 2009). The global financial crisis resulted in a dramatic drop in the prices of farmed fish, including the European marine farmed fish species with consequences for this thriving exporting sector of Greece (Anastasiou et al., 2014; Tveteras \& Lien, 2009).

Job satisfaction of employees may be affected during periods that they experience salary cuts (Gardner \& Oswald, 2007) and management is under pressure to reduce the production cost and maintain the business afloat when consumption levels of the farmed fish suddenly falls. This is what happened in the last three years in the Greek aquaculture industry (Anastasiou et al., 2014).

The purpose of this study is to assess the levels of job satisfaction of production Managers in Greek Fish farms and to investigate the possible link between job satisfaction and other human resources parameters of production managers in Greek Aquaculture firms.

\section{Method}

This study was conducted to investigate the levels of job satisfaction of Managers from Fish farms in Greece. Managers from eighteen fish farms were interviewed, data for the number of employees, productivity length of service, age, level of education and participation in the decision making process were collected. Furthermore a questionnaire for job satisfaction was used to evaluate the level of job satisfaction of the interviewed managers in fish farms. The questionnaire had a seven - point response scale (from Extremely Dissatisfied to Extremely Satisfied) according to Sutherland \& Cooper (1992). The questionnaire of Sutherland \& Cooper (1992) has been adapted for usage in Greece (Anastasiou \& Papakostantinou, 2014) and includes questions which explore dimensions of job satisfaction such as level of responsibility, job variety, work climate, the nature of the work, recognition, working hours, wages. 
Questionnaires were distributed to the production sites of the first 6 fish farms included in the business directory data of 4 different regions with Fish farms in Greece. Of the 24 questionnaires sent, 18 were received giving a response rate of $72 \%$.

\section{Results}

The sample of Production managers included eighteen men and there were no women present. This shows a male dominance in the Aquaculture sector of Greece. The level of job satisfaction and other parameters investigated are presented din Table 1 . The majority (77.7\%) of the sample had age $>30$ and $44 \%$ of them had postgraduate qualifications. The length of service varied between 6 and 20 years with an average 13.72 years of service. The annual salary ranged between $22 \mathrm{~K}$ and $38 \mathrm{~K}$ with an average 30,670 Euros (Table 1). The results of the correlation analysis between job satisfaction and other parameters investigated in present work are presented in Table 2.

Table 1. Productivity ( $\mathrm{kg}$ of produced fish/employee/pcm) of the fish farms and managers $(\mathrm{n}=18)$ job satisfaction, age, length of service, annual salary, level of education ( $1=$ Degree, $2=\mathrm{MSc}, 3=\mathrm{PhD})$ and participation of the staff in the decision making process of the company (Average values $\pm \mathrm{SD}$ )

\begin{tabular}{ccccccc}
\hline Productivity & Job satisfaction & Age & $\begin{array}{c}\text { Length of } \\
\text { service }\end{array}$ & Salary (thousands) & $\begin{array}{c}\text { Level of } \\
\text { education }\end{array}$ & $\begin{array}{c}\text { Participation in the } \\
\text { decision making }\end{array}$ \\
\hline 1102,11 & 72,73 & 41,17 & 13,72 & 30,67 & 1,50 & 5,00 \\
$(471,79)$ & $(11.69)$ & $(9.38)$ & $(5.24)$ & $(4.76)$ & $(0.60)$ & $(1.15)$ \\
\hline
\end{tabular}

Table 2. Correlations of job satisfaction and other parameters of production managers in Greek fish farms $(\mathrm{n}=18)$

\begin{tabular}{ccccccc}
\hline & Age & $\begin{array}{c}\text { Length of } \\
\text { Service }\end{array}$ & $\begin{array}{c}\text { Level of } \\
\text { Education }\end{array}$ & $\begin{array}{c}\text { Fish farm } \\
\text { Productivity }\end{array}$ & $\begin{array}{c}\text { Participation in Decision } \\
\text { making }\end{array}$ & Salary \\
\hline Job satisfaction & $0.29 *$ & -0.24 & -0.05 & $0.16^{*}$ & $0.31^{*}$ & $0,21^{*}$ \\
\hline
\end{tabular}

Significant correlation is indicated with asterisks, * Correlation is significant $(\mathrm{P}<0.05)$ Spearman Correlation.

\section{Discussion}

There were no women in the sample and this appears to be the case in the Managerial positions in most of the fish farms in Greece. The interviewed production managers considered this a common fact which is partially explained by the work experience required by production managers who may start their professional work when young and after gaining hands on experience in a variety of job tasks which involve lifting weights and exposure to hard working conditions they may be promoted to the position of production managers. This is in agreement with other countries with a low presence of women in the some agricultural jobs which are considered as hard, involving physical strain and exposure to occupational risks as in Aquaculture, has been reported in several countries including Greece (Tyligadas et al., 2014).

The results indicate that Production Managers in Greek Fish farms exhibit high level of job satisfaction with more than $44 \%$ of them exhibiting job satisfaction levels $>70$.

The perceived level of participation of the staff in the decision making process of the company was high with values ranging from 3 (a low degree of participation) to 7 (Table 1).

The correlation analysis between job satisfaction and other parameters investigated in present work (Table 2), indicate positive effect of the participation in decision making process $(0.29, \mathrm{P}<0.01)$, the age $(0.29, \mathrm{P}<0.05)$, salary $(0.21, \mathrm{P}<0.05)$ and the productivity of the farm $(0.16, \mathrm{P}<0.05)$ on the job satisfaction of the Production managers.

In the same manner, job satisfaction of other professions may be affected by a variety of parameters including those reported in the present work (Anastasiou \& Papakonstantinou 2014; Erbasi \& Arat, 2012).

Interestingly, the data presented here, indicate a negative effect of the length of stay $(-0.24, \mathrm{P}<0.05)$ on job satisfaction. This is an alarming result, production managers may be experience difficulties in coping with the current difficult economic conditions that Greek fish farms are exposed to as a results of the financial crisis. Under these adverse economic conditions of Greece, several businesses including the fish farms reduced the 
volume of production, the number of their employees and the wages and bonuses.

The latest available data indicate that during the last three years, the total number of employees had fallen by $-8 \%$ in 2013 (Tyligadas et al., 2014). In fact the industry is still suffering and frequently workers are paid arrears ranging from two to four months (Anastasiou et al., 2014). Reduced wages may have a negative effect on the job satisfaction of employees (Ali \& Ahmed, 2009).

The results presented in here, indicate that in spite of adverse financial conditions in Greece, this exporting agriculture sector has Production managers who are exhibiting high level of job satisfaction which is positively influenced by Management practices which enhance the level of participation in the decision making process of the fish farms.

The human resources of any business is the capital which can be the driving force for success in the future, enhancing the positive contribution of Human resource management policies which can increase the level of job satisfaction of the personnel should always be a priority especially during period of financial crisis (Panagopoulos \& Anastasiou, 2014).

The results presented in the present work are important for the aquaculture industry. The job satisfaction of agricultural personal may help to increase the productivity of agricultural business (Mullinge \& Mueller 1998; Pollnac et al., 2001). An employee with high job satisfaction appears to have generally positive attitudes, while one who is dissatisfied to have negative attitudes towards their job (Robbins, 2003; Fahr, 2011).

The limitations for this study must also be noted. The data has been collected once and from a small number of firms. Longitudinal data may produce different results as the level of motivation of employees may vary at certain period of time and with growing experience (Danish \& Usman, 2010). Future research could also investigate differences in the job satisfaction between production managers who are working on-site and senior managers. As there is some evidence to suggest that the job satisfaction may vary according to managerial level and organizational status (Rahimic, 2013). It would also be interesting to investigate the levels of job satisfaction of employees in aquaculture and other agricultural sectors.

\section{Conclusion}

The present work presents the results of a research on the level of job satisfaction of Greek fish farm managers. The results indicate that aquaculture managers in Greece exhibited high level of job satisfaction. The results of correlation analysis indicate that job satisfaction is mostly increased with increasing level of participation in the decision making, wages and age and to a small degree by the productivity of the fish farms.

\section{Acknowledgments}

This research has been co-financed by the European Union (European Social Fund - ESF) and Greek national funds through the Operational Program "Education and Lifelong Learning" of the National Strategic Reference Framework (NSRF) - Research Funding Program: ARCHIMEDES III. Investing in knowledge society through the European Social Fund. Project title "Monitoring the quality of farmed fish in NW Greece.

\section{References}

Ali, R., \& Ahmed, M. S. (2009). The impact of reward and recognition programs on employee's motivation and satisfaction: an empirical study. International Review of Business Research Papers, 5(4), 270-279.

Amin, M., Ismail, W. K. W., Rasid, S. Z. A., \& Selemani, R. D. A. (2014). The impact of human resource management practices on performance: Evidence from a Public University. The TQM Journal, 26(2), 125-142. http://dx.doi.org/10.1108/TQM-10-2011-0062

Anastasiou, S., \& Papakostantinou, G. (2014). Factors affecting job satisfaction, stress and work performance of Secondary Education teachers in Epirus, NW Greece. International Journal of Management in Education. 8(1), 37-53. http://dx.doi.org/10.1504/IJMIE.2014.058750

Anastasiou, S., Panta, M., Dais, E., \& Nathanailides, C. (2014). Economic and Marketing Parameters of the Greek Marine Aquaculture Industry during Growth and Recession. Proceeding of the 9th MIBES Iinternational Conference (pp. 102-110). Thessaloniki, Greece 3oth June-1 ${ }^{\text {st }}$ July, 2014. http://mibes.teilar.gr/proceedings/2014/Anastasiou-Panta-Dais-Nathanailides.pdf

Bourantas, D., Anagnostelis, J., Mantes, Y., \& Kefalas, A. G. (1990). Culture gap in Greek management. Organization Studies, 11(2), 261-283. http://dx.doi.org/10.1177/017084069001100205

Brown, S. P., \& Peterson, R. A. (1994). The effect of effort on sales performance and job satisfaction. The Journal of Marketing, 58(2), 70-80. http://dx.doi.org/10.2307/1252270 
Bush T., \& Middlewood, D. (2006). Leading and Managing People in Education. London: Sage.

Danish, R. Q., \& Usman, A. (2010). Impact of reward and recognition on job satisfaction and motivation: An empirical study from Pakistan. International Journal of Business and Management, 5(2), 159-167. http://dx.doi.org/10.5539/ijbm.v5n2p159

Ellickson, M., \& Logsdon, K. (2001). Determinants of job satisfaction of municipal and government employees. State and Local Government Review, 33(3), 173-84. http://dx.doi.org/10.1177/0160323X0103300302

Erbasi, A., \& Arat, T. (2012). The Effect of Financial and Non-financial Incentives on Job Satisfaction: An Examination of Food Chain Premises in Turkey. International Business Research, 5(10), 136-151. http://dx.doi.org/10.5539/ibr.v5n10p136

Fahr, R. (2011). Job design and job satisfaction: Empirical evidence for Germany? Management Revue, 22(1), 28-46. http://dx.doi.org/10.1688/1861-9908_mrev_2011_01_Fahr

Gardner, J., \& Oswald, A. J. (2007). Money and mental wellbeing: A longitudinal study of medium-sized lottery wins. Journal of Health Economics, 26(1), 49-60. http://dx.doi.org/10.1016/j.jhealeco.2006.08.004

Gazioglu, S., \& Aysit, T. (2006). Job satisfaction in Britain: individual and job related factors. Applied Economics, 38, 1163-1171. http://dx.doi.org/10.1080/00036840500392987

Green, E. G. T., Deschamps, J. C., \& Páez, D. (2005). Variation of individualism and collectivism within and between 20 countries. Journal of Cross-Cultural Psychology, 36(3), 321-339. http://dx.doi.org/10.1177/0022022104273654

Hofstede, G. (1980). Culture's Consequences: International Differences in Work-Related Values. London.

Kristensen, N., \& Johansson, E. (2008). New evidence on cross-country differences in job satisfaction using anchoring vignettes. Labour Economics, 15(1), 96-117. http://dx.doi.org/10.1016/j.labeco.2006.11.001

Maghradi, A. (1999). Assessing the effect of job satisfaction on managers. International Journal of Vaule- Based Management. 12(1), 1-12.

Markovits, Y., Davis, A. J., \& Van Dick, R. (2007). Organizational commitment profiles and job satisfaction among Greek private and public sector employees. International Journal of Cross Cultural Management, 7(1), 77-99. http://dx.doi.org/10.1177/1470595807075180

Mulinge, M., \& Mueller, C. W. (1998). Employee job satisfaction in developing countries: the case of Kenya. World Development, 26(12), 2181-2199. http://dx.doi.org/10.1016/S0305-750X(98)00089-8

Mullins, L. (2002). Management and Organisational Behaviour with Management. Pearson Education.

Naqvi, S. R., Ishtiaq, M., Kanwal, N., \& Ali, M. (2013). Impact of Job Autonomy on Organizational Commitment and Job Satisfaction: The Moderating Role of Organizational Culture in Fast Food Sector of Pakistan. International Journal of Business and Management, 8(17), 92-101. http://dx.doi.org/10.5539/ijbm.v8n17p92

Nel, P. S., Haasbroek, G. D., Schultz, H. B., Sono, T., \& Werner, A. (2004). Human resources management (6th ed.). Cape Town: Oxford University Press.

Panagopoulos, N., Anastasiou, S., \& Goloni, V. (2014). Professional Burnout and Job Satisfaction among Physical Education teachers in Greece. Journal of Scientific Research \& Reports, 3(13), 1710-1721. http://dx.doi.org/10.9734/JSRR/2014/8981

Papakostantinou, G., \& Anastasiou, S. (2013). Principles of Human Resource Management. Athens: Gutenberg (in Greek).

Pollnac, R. B., Pomeroy, R. S., \& Harkes, I. H. (2001). Fishery policy and job satisfaction in three southeast Asian fisheries. Ocean \& Coastal Management, 44(7), 531-544. http://dx.doi.org/10.1016/S0964-5691(01)00064-3

Rahimic, Z. (2013). Influence of Organizational Climate on Job Satisfaction in Bosnia and Herzegovina Companies. International Business Research, 6(3), 129-139. http://dx.doi.org/10.5539/ibr.v6n3p129

Robbins, S. (2003). Organizational behaviour (9th ed.). New Jersey: Prentice Hall.

Sempane, M., Rieger, H., \& Roodt, G. (2002). Job satisfaction in relation to organisational culture. South African Journal of Industrial Psychology, 28(2), 23-30.

Simosi, M. (2013). Trajectories of organizational commitment: A qualitative study in a Greek public sector 
organization. International Journal of Cross Cultural Management, 13(1), 111-130. http://dx.doi.org/10.1177/1470595812452637

Spector, P. (1997). Job Satisfaction: Application, Assessment, Causes and Consequences. California:Sage.

Sutherland, V. J., \& Cooper, C. L. (1992). Job stress, satisfaction and mental health among general practitioners before and after introduction of new contract. British Medical Journal, 304, 1545-1548. http://dx.doi.org/10.1136/bmj.304.6841.1545

Tveteras, R., \& Lien, K. (2009). Recession Affects European Seafood Markets. Global aquaculture advocate. $125,33-38$.

Tyligadas, I., Moutopoulos, D. K., Chatziefstathiou, M., Tsoumani, M., Nathanailides, C., \& Anastasiou, S. (2014). A Review of Health and Safety Issues in Mariculture Industry in Greece. Journal of Scientific Research \& Reports, 3(9), 1153-1161. http://dx.doi.org/10.9734/JSRR/2014/8886

Yurtseven, G., \& Halici, A. (2012). Importance of the motivational factors affecting employee's satisfaction. International Business Research, 5(1), 72-76.

\section{Copyrights}

Copyright for this article is retained by the author(s), with first publication rights granted to the journal.

This is an open-access article distributed under the terms and conditions of the Creative Commons Attribution license (http://creativecommons.org/licenses/by/3.0/). 